\title{
Kalwińskie budowle kościelne na terenie Wielkiego Księstwa Litewskiego w okresie nowożytnym*
}

Jościół ewangelicko-reformowany w Wielkim Księstwie Litewskim
nowożytnej Rzeczypospolitej był niemalże wzorcowo zorganizowaną strukturą religijną. Jego członkowie skupiali się wokół grupy liderów religijnych i politycznych posiadających jednocześnie silne wpływy ekonomiczne. Ducha tej wspólnoty najlepiej oddawała nazwa kościoła: Jednota Litewska, wskazując na funkcjonowanie prężnej organizacji kościelnej jednoczącej zwolenników teologii Kalwina zamieszkujących Wielkie Księstwo. W istocie można mówić niemalże o kościele krajowym, działającym na jasno określonym terytorium politycznym. W ramach Jednoty w II połowie XVI i na początku XVII wieku działała grupa przywódców duchowych, zainteresowanych budową trwałych struktur kościelnych. Narzędziem do tworzenia własnej identyfikacji konfesyjnej było wydrukowanie w Brześciu własnej biblii, zwanej od miejsca druku Biblią brzeską ${ }^{1}$, którą w 1617 roku

* Tekst niniejszy powstał dzięki współrealizacji projektu badawczego NCN „Maestro 2” NCN 2012/04/A/HS2/00435-UWr 4602/PB/IHS/12: Protestanckie budownictwo w Europie w XVI-XVIII wieku w Europie.

1 U. Augustyniak, „Druga reformacja” w Wielkim Ksiestwie Litewskim w 1 połowie XVII wieku. W poszukiwaniu tożsamości myznaniowej, [w:] Sztuka i dialog myzৃań w XVI i XVII wieku. Materiaby sesji Stowarzyszenia Historyków Sztuki, Wroctaw, listopad 1999, red. J. Harasimowicz, Warszawa 2000, s. 223. O strukturze i historii Kościoła Ewangelicko-Reformowanego na Litwie zob. 
synod Jednoty uznał za obowiązowy element wyposażenia każdego budynku zborowego. Istotnym czynnikiem wspomagającym rozwój litewskiej reformacji był język polski, który stał się jednym z głównych narzędzi zmian w pejzażu wyznaniowym Księstwa. Poprzez Biblię brzeską i polskojęzyczne traktaty można było zapoznać się nie tylko z Pismem Świętym, ale z szeroką wymianą myśli na łonie protestantyzmu².

Wśród litewskiej szlachty wyznanie kalwińskie pełniło podobna rolę jak luteranizm w Prusach Królewskich czy Książęcych, stanowiąc swoiste spoiwo społeczne i religijne budującego się powoli nowożytnego społeczeństwa. $\mathrm{Na}$ Litwie idee reformacyjne najszybciej chłonęło niemieckojęzyczne mieszczaństwo i litewsko- lub polskojęzyczna szlachta. Na Litwie obydwa wyznania protestanckie cieszyły się stosunkowo dużą swoboda wyznania, ukształtowaną przez zakorzenioną tolerancję religijną. Wpływ na nią miały zamieszkujace te tereny różne grupy narodowościowe i wyznaniowe jak Tatarzy, Karaimowie czy prawosławni, ciesząc się, podobnie jak luteranie, patronatem Radziwiłłów birżańskich ${ }^{3}$.

Przyjęcie reformacji w Wielkim Księstwie Litewskim było, jak nieraz pisano, najlepszą alternatywą dla Litwinów, którzy nie musieli w ten sposób wybierać pomiędzy polskim katolicyzmem a ruskim prawosławiem ${ }^{4}$. Po-

M. Kosman, Litenskea Jednota Ewangelicko-reformowana od potony XVII w. do 1939 roku, Opole 1986, s. 1 i nast. W przeciwieństwie do kalwinistów luteranie nie zbudowali własnej ponadzborowej struktury kościelnej, a ich wypływy, ja np. w Kownie ograniczały się do miast.

2 Biblia brzeskea - historia, jesyk, kultura, red. r. Leszczyński, Wrocław 2013; H. Lulewicz, Radzinitt Mikotaj, [w:] Polski stownik biograficzny, t. XXX, s. 343, Lietuvos mokslų akademijos Vrublevskiu biblioteka, Vilnius (dalej: LMAB), sygn. F 40/239, Krótki rys historji z̧boru wileńskiego ew. reformowanego, s. 180, ibidem, sygn. F40/516, Zbór Kopyski, s. 179. Inwentarz wymienia: „Biblie duże Brzeskie, iedna Nowa z Klauzrkami Srebrnemi, Druga w Czarnej Oprawie”.

3 T. Wasilewski, Tolerancja w Wielkim Ksiestwie Litenskim w XVI-XVII wieku, [w:] Odrodzenie i Reformacja w Polsce, r. 19, 1974, s. 117-128; M. Kosman, Protestanci i kontrreformacja. Z driejón tolerancii wyznaniowej w Rzecsypospolitej XVI-XVIII wieku, Wrocław 1978; A. Mironowicz, Tolerancja uyznaniowa na kresach wschodnich Rzecsypospolitej, [w:] Między Zachodem a Wschodem. Studia z. dziejów Rzecsypospolitej w epoce nowosiytnej, red. J. Staszewski, K. Mikulski, J. Dumanowski, Toruń 2002, s. 339-347; R. Dzięgiel, Protestanci i prawostawni, Patronat wyznaniony Radzimittón birżanskich nad Cerkwia prawostawna w ksiestwie stuckim w XVII wieku, Warszawa 2000, s. 16-31.

4 T. Kempa, Luteranie w Wielkim Ksiestwie Litewskim, [w:] Kościoly luterańskie na ziemiach polskich (XVI-XX w.) w czasach Rzeczypospolitej, red. J. Kłaczkow, Torun 2012, s. 92, M. Kosman, Protestanci..., s. 20. 
twierdził to Krzysztof Radziwiłł zw. Piorunem, w 1589 roku fundując zbór w Birżach: „W tymże zamku zbudowaliśmy kościół ku zgromadzaniu się i schadzaniu ludzi chrześcijańskich nie na rzymską ani grecka, ale na religię

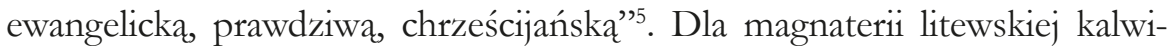
nizm był środkiem budowy niezależnych relacji z Rzeczypospolitą i potwierdzeniem własnej tożsamości narodowej. Jako republikański w swym charakterze od demokratycznego luteranizmu, kalwinizm bardziej odpowiadał sposobowi szlacheckiego sprawowania władzy na Litwie. Chwalono się większą surowością obyczajów i konserwatywną wiernością ortodoksyjnej wierze reformowanej, co sprzyjało dłuższemu zachowaniu niezależności wyznaniowej. Konfesja reformowana stała się w XVII wieku silniejszym spoiwem jedności stanowej, w przeciwieństwie do wcześniejszej dziedzicznej przynależności do stanu szlacheckiego.

Szlachta kalwińska starała się początkowo jak najlepiej dbać o zbory należące do tego wyznania i chronić je przed atakami katolików. W połowie XVI wieku z kalwinizmem identyfikowało się blisko 50 senatorów oraz liczne rody średniej szlachty (około 155 rodzin o różnym stopniu zamożności). Wyznanie to miało swych zwolenników wśród przedstawicieli domów Radziwiłłów, Chodkiewiczów, Sapiechów, Zawiszów i Tolwoszy $^{6}$. Osiagnięta w II połowie XVI wieku dominacja religijna kalwinistów skończyła się wraz ze śmiercią ich największych politycznych protektorów. W połowie XVII wieku przy kalwinizmie ostali się jeszcze Janusz i Bogusław Radziwiłłowie, Gedeon, Jerzy i Teofil-Dunin Rajeccy, Mikołaj Abramowicz czy Matiasz Frąckiewicz-Radzimiński. Inicjatywę przejęli katolicy stanu duchownego, jak i świeccy, spychając przedstawicieli wyznania helweckiego do defensywy. Już w połowie XVII wieku słabość polityczna tego wyznania objawiła się bezsilnością Bogusława Radziwiłła interweniującego w sprawie zajmowanych bezprawnie przez księży katolickich zborów kalwińskich. Wpływ szlachty kalwińskiej na stan bezpieczeństwa budynków

5 H. Merczyng, Zbory $i$ senatorowie protestanccy w dawnej Rzeczypospolitej, Warszawa 1904 s. 84; W. Krasiński, Zarys dziejów reformacii w Polsce, Warszawa 1903, t. I, s. 208.

6 J. Lukaszewicz, Drieje kościołón wyznania helweckiego na Litwie, Wilno 1842, s. 16-17; B. Zwolski, Sprawa zboru ewangelicko-reformowanego w Wilnie w latach 1639-1641, Wilno 1936, s. 8; K. Chodynicki, Reformacja w Polsce, Warszawa 1921, s. 28. 
zborowych był coraz słabszy. Biskupi katoliccy wręcz decydowali o zamykaniu zborów albo wyrażali zgodę, jak w przypadku zboru w Żupranach, na ich remont lub odbudowę ${ }^{7}$.

Zanim to jednak nastapiło w I połowie XVI wieku kształtował się nowy pejzaż religijny. Na Litwie jako pierwsza rozpowszechniła się reformacja luterańska, bo proluterańskie sympatie najszybciej okazywali niemieckojęzyczni mieszczanie, tworząc własne zbory w Wilnie i Kownie. Sprzyjający luteranizmowi Mikołaj Radziwiłł w głównej sali zamku w Brześciu kazał powiesić dwie tapiserie sprowadzone z Niderlandów: pierwszą z wizerunkiem Marcina Lutra i druga przedstawiająca scenę Chrztu w Jordanie $e^{8}$. W połowie XVI wieku nastapił jednak szybki zwrot w stronę kalwinizmu, a kalwiniści zaczęli spotykać się najpierw w Wilnie, a następnie w zborach wznoszonych sukcesywnie w latyfundiach magnackich. Wyznanie to stopniowo przenosiło się do miast leżących coraz dalej na wschód, w stronę domeny prawosławia. W końcu XVI wieku powstały zbory ewangelicko-reformowane w Połocku, Mińsku i Witebsku?. Warto od razu zauważyć, że budując zbór w Witebsku, wypełniono wolę króla, który nakazał, aby tutejszy dom „ku słuchaniu Słowa Bożego” nie powstał ani w przejętym kościele katolickim, ani w cerkwi prawosławnej (zdarzały się i takie przypadki) tylko został wzniesiony na nowo ${ }^{10}$.

W związku z tym, że luteranizm adresowany był w zasadzie do niemieckojęzycznego mieszczaństwa, a kalwinizm do litewskiej szlachty, obie grupy nie rywalizowały zbytnio ze soba, w 1570 roku i w 1578 roku odbywając w Wilnie wspólne synody i uważnie obserwując działania kontrreformacji na Litwie. Efektem spotkań synodalnych był nie tylko wpływ obydwu wyznań na słynną ugodę sandomierska, ale także powstanie doku-

7 W. Krasiński, op.cit., s. 228.

8 Zbiór pomnikón reformacji. Akta, tho iest sprany zboru krześcijańskiego Wileńskiego, które sie poczeli r.P. 1557 Miesiaca Decembra dnia 14, (przedruk), Wilno 1913, s. II.

9 T. Kempa, Wobec kontrreformacii. Protestanci i prawostawni w obronie swobód wyznaniowych w Rzecsypospolitej w końcu XVI i w pierwszej potowie XVII wieku, Toruń 2007, s. 34.

10 Zbiór pomnikón reformacyi kościoła polskiego i litenskiego, zabytki z XVI wieku, Wilno 1911, s. 7-9. Zbór w Witebsku zostal wzniesiony w 1562 roku na terenie dolnego zamku przy ul. Wielkiej i uposażony przez Pawła i Jerzego Druckich-Sokolińskich. W 1665 roku budynek zniszczono, a kaznodzieję ks. Raniszewskiego z rodziną uprowadzono do Moskwy. Z kolei w Słucku zbór zorganizowano w dawnej cerkwi pw. św. Katarzyny. 
mentu „Concordia Vilnensis”, ułatwiającego współpracę obydwu wyznań. Razem protestowano przeciw różnym tumultom wszczynanym w Wilnie przez jezuickich studentów akademii wileńskiej. Wielu litewskich luteranów pobierało nauki w kalwińskich, radziwiłłowskich gimnazjach w Kiejdanach i w Słucku11. W 1585 roku oba wyznania zorganizowały w Wilnie dysputę mająca, wbrew nastrojom w Koronie, ugruntować na terenie Wielkiego Księstwa Litewskiego ustalenia zgody sandomierskiej.

Tylko kalwiniści musieli bronić się znacznie częściej od luteran, przed coraz zacieklejszymi atakami kontrreformacji jezuickiej ${ }^{12}$. Luteranie i kalwiniści podejmowali ścisłą współpracę i skutecznie bronili się w 1610 roku przed roszczeniami proboszcza kościoła św. Jana, który wsparty przez wileńskiego biskupa Benedykta Woynę pozwał ich do sądu o zaległe opłaty na rzecz Kościoła rzymskiego, celem pozyskania środków na odbudowę kościołów Wilna po pożarze 1 lipca 1610 roku. Występując wspólnie do króla pod przewodnictwem Janusza Radziwiłła i Piotra Nonharta uzyskali o dziwo wsparcie Zygmunta III i oddalenie pozwu. Dopiero gdy nie było w mieście kalwinistów, luteranie skupiali na sobie całą uwagę kontrreformacji (o ile kontrreformacją można nazwać profanację w 1606 roku luterańskiego cmentarza w Kownie czy ostrzelanie cztery lata później przez miejski motłoch kościoła luterańskiego i domu pastora $)^{13}$.

Zanim jednak nastapił regres ekspansji tego wyznania, kalwinizm najszybsze postępy poczynił na Żmudzi i na Białorusi, gdzie kościół katolicki miał stosunkowo słabo rozwiniętą strukturę organizacyjna. Na sobór

11 LMAB, sygn. F 40/253, s. 1-3, oraz F40 1024, s. 26. Przy kościele w Słucku była szkoła fundacji Janusza Radziwiłła z 12 maja 1617 roku, która podobnie jak ta w Kiejdanach miały kształcić uczniów w duchu reformacyjnym i przeciwdziałać posyłaniu ich do szkół katolickich, zob. też I. Lukšaitė, Die reformatorischen Kirchen Litauens bis 1795, [w:] Die reformatorischen Kirchen Litauens. Ein historischer Abriss, hersg. von A. Hermann, W. Kahle, Erlangen 1978, s. 131; Akta synodow prowincjonalnych Jednoty Litewskiej 1611-1625, Wilno 1915, s. XIV.

12 T. Kempa, Luteranie..., s. 124-136.

13 I. Lukšaite, Die reformatorischen..., s. 108; B. Zwolski, op.cit., s. 8-9; H. Wisner, Usuniecie z.boru ewangelickiego ₹. Wilna 1639-1640, [w:] idem, Rzeczpospolita Warón. Czasy Zygmunta III $i$ Wtadystawa IV, Warszawa 2002, s. 293-312; T. Kempa, Wobec kontrreformacji..., s. 471-483, M. Kosman, Jednota litewska..., s. 36 pokazuje, że prześladowania luteran miały zupełnie innych charakter. 
do Wilna zwołany w 1555 roku przez biskupa Paca przyjechało niewielu księży, większość opowiedziała się bowiem już po stronie protestantyzmu. W opisie wizytacyjnym diecezji żmudzkiej dokonanym w latach 1593-1596 wzmiankowano 21 parafii protestanckich wykorzystujących dawne kościoły katolickie $^{14}$. Kalwiniści rezydowali m.in. w Widuklach, Betygole, Krożach, Krokiszkach, Skirstymoniu, Ejragole, Kołtynianach. Nawet w stolicy biskupiej w Worniach i jej bezpośredniej okolicy znajdowały się kolejne, niezidentyfikowane dziś jednoznacznie zbory kalwińskie ${ }^{15}$.

W stołecznym Wilnie nabożeństwa reformowane odprawiano około 1553 roku w kaplicy wybitej czarną tkanina, mieszczącej się w pałacu Radziwiłłów na Lukiszkach $^{16}$. Jej wystrój był bardzo surowy. Na stole, pomiędzy dwoma świecznikami w kształcie putt ustawiono biały krzyż, drugi zaś, także tego koloru, powieszono obok, na ścianie. W grudniu 1557 roku zorganizowano w tejże kaplicy pierwszy synod kalwiński, na który przyjechało 50 duchownych, pierwszym seniorem podczas ,schadzek” obierając Szymona Zaciusza ${ }^{17}$. Ze względu na szybki wzrost liczby członków helweckiego wyznania trzeba było udostępnić im większe pomieszczenie. Jak pisano: „Kościoły tu prawie opustoszały, gdyż wszystkich pociągnął Radziwiłł, nie tyle ze względów politycznych, ile ze względu na swój autorytet, bo on tu więcej znaczy niż wszyscy biskupi razem wzięci”. W 1559 roku rada miasta odmówiła katolikom budowy czterech ołtarzy na święto Bożego Ciała,

14 G. Błaszczyk, Diecezja żmudzka od XIV do poczqtku XVII wieku. Ustrój, Poznań 1993, s. 183-184. W latach 1559-1613 miały zaś istnieć na Żmudzi ok. 32 zbory ewangelickie, V. Vaivada, Kataliku Bažnyčia ir Reformacija Žemaitijoje XVI a.: esminiai raidos bruožai, Klaipèda 2004, s. 189-190. Według dość niepewnych danych biskupa Wołonczewskiego, pod koniec XVI wieku na Żmudzi miało znajdować się 10 kościołów luterańskich i aż 41 świątyń kalwińskich. Niewątpliwie są to dane zawyżone, M. Wołonczewski, Biskupstwo żmujdžkie, Kraków 1898, s. 46.

15 I. Lukšaite, Die reformatorischen..., s. 58; H.-Ch. Diedrich, „Auf dem Weg zur Glaubenseinheit...", w: Reformationsgeschichte Weißrusslands, Erlnagen 2005, s. 200-201.

16 J. Minkevičius, Lietuvos Architektüros Istorija. Nuo seniausiu laiku Iki XVII a. vidurio, T. I, Vilnius 1987, s. 229-230, Zbiór pomników reformacyi..., s. 188-189. Tu omówiona hipotetyczna lokalizacja pałacu.

17 LMAB F 40/239, Krótki rys historji zboru wileńskiego ew. reformowanego, s. 36, Zbiór pomników reformacji. Akta, tho iest..., s. II. Synod ten uważany był za symboliczny początek wyznania helweckiego na Liwie. 
godząc się jedynie na budowę dwóch na własny koszt, pozostałe dwa katolicy musieli wznieść sobie sami ${ }^{18}$.

Radziwiłłowie około 1560 roku przeznaczyli na nowy zbór kamienicę Stanisława Gasztołda, czyli jego dawny pałac miejski. Dom ten, jako dom modlitwy, pozostał w rękach kalwinistów do 1574 roku, czyli do czasu usunięcia go stamtąd na polecenie gorącego katolika Mikołaja Krzysztofa Radziwiłła zw. Sierotką i na żądanie nuncjusza papieskiego. Kalwiniści zajęli tzw. Rybny Rynek (koło cerkwi przy ul. Wielkiej), na którym ustawiono namioty służące im przez kilka lat jako prowizoryczny dom modlitwy $^{19}$. To w „kamienicy pogasztołdowskiej”, po zgonie Mikołaja Radziwiłła zw. Czarnym (oddał Bogu ducha w nocy z 28 na 29 maja 1565 roku), na czas jakiś złożono jego ciało. Tu przed pogrzebem spoczęło ciało jego żony, Elżbiety Radziwiłłowej z Szydłowieckich. Mikołaj w swym testamencie pisał: „, pogrzeb ciału mojemu chcę mieć w tymże kościele, gdzie i małżonka moja pochowana, w domu moim, który jest w rynku przez ulicę naprzeciwko domów panów Ościków"20. To do kamienicy pogasztołdowskiej magnat zaprosił króla Zygmunta Augusta, by wziął udział w kalwińskim nabożeństwie i zapisał tutejszej wspólnocie w swym testamencie nakład Biblii brzeskiej: ,a na tot kostieł, gdie tieło moje pochowano budie, a na szkołu dopisuju wsie biblii nakładom moim drukowane w Bieresti’"21.

Po utracie budynku zborowego Mikołaj Radziwiłł zw. Rudym sprzedał 15 lutego 1577 roku zborowi na nową siedzibę swój wileński dom położo-

18 M. Kosman, Reformacja i kontrreformacja w Wielkim Księstwie Litewskim w świetle propagandy wyznaniowej, Wrocław 1878, s. 45.

19 Zbiór pomnikón reformacyi..., s. 39.

20 Ibidem, s. 189; J. Łukaszewicz, op.cit., s. 18-19. W kamienicy pogasztołdowskiej miały być pochowane zwłoki Mikołaja i Elżbiety. W XIX wieku wspominano jakąś drewniana, starą kapliczkę, która miała upamiętniać ten pochówek. Najpewniej dopiero po „oczyszczeniu od heretyków” pałacu pogasztołdowskiego w 1574 roku ciało Czarnego przeniesiono do Dubinek, gdzie pochówek upamiętniono odpowiednim pomnikiem z marmuru zachowanym jeszcze w 1692 roku. Elżbieta spoczęła w Żakiszkach, zob. W. Krasiński, op.cit., s. 208.

21 Zbiór pomnikón reformacyi..., s. XI; J. Łukaszewicz, op.cit., s. 18-19, LMAB F 40/239, Krótki rys historji zboru wileńskiego ew. reformowanego, s. 23-30. Radziwiłł zaprosił króla na nabożeństwo reformowane do swej wileńskiej kaplicy w pałacu, ale jego uczestnictwo zablokował sufragan wileński Cyprian, który zastąpił drogę królowi wraz z duchowieństwem, które niosło krzyż i obrazy. 
ny na świętomichalskim zaułku, zw. „Hornostajskim dworem”, otrzymując zań 8000 kop groszy litewskich pochodzących ze składek tutejszych kalwinistów (przepraszając niejako, że ze względu na swoje potrzeby musi zażądać wynagrodzenia). W 1582 roku, kiedy dom ów zastąpiono budynkiem kościelnym „ku przepowiadaniu prawdziwego słowa Bożego”, kanclerz litewski Ostafi (Eustachy) Wołłowicz podarował dodatkowo wspólnocie reformowanej kolejny dom z przeznaczeniem na szpital, a na cmentarz nowy plac (zapewne przy ul. Zawalnej) ${ }^{22}$. W 1590 roku zborownicy dokupili od Piotra Stabrowskiego za 2000 kop groszy dom leżący na ul. Wielkiej, przy tzw. Rybim Rynku, naprzeciw kamienicy pogasztołdowskiej, przeznaczając go prawdopodobnie na własną szkołę wyznaniowa. Obok, w domu Bielikiewiczów powstała reformacyjna drukarnia Daniela Lęczyckiego. W 1609 roku wspólnota wzbogaciła się o kolejny budynek, tym razem o kamienicę zw. Konstantynowską (należącą wcześniej do księcia Konstantego Ostrogskiego), którą, z przeznaczeniem na szpital, otrzymała w prezencie od hetmana wielkiego i wojewody wileńskiego Krzysztofa Radziwiłła. Jako że znajdująca się obok kamienica zw. z kolei Sołtanowską należała do gminy luterańskiej (luterski ludwisarz Hancewicz zapisał ja na szpital zborowy), to paradoksalnie cała pierzeja ul. Zamkowej, vis-á-vis katolickiego kościoła św. Jana, twierdzy kontrreformacji, należała do obydwu wyznań ewangelickich (stąd w XVI i XVII wieku jej nazwa: ul. Zborowa) ${ }^{23}$.

Wileńscy kalwiniści przetrwali kilkukrotne niszczenie swej wileńskiej świątyni w latach: 1591 (straty oszacowano wtedy na 1000 kop groszy) ${ }^{24}$

22 Zbiór pomnikón reformacyi..., s. 37. Tu dokładne położenie domu „z cegły i drzewa”, sąiadującego też z pałacem księcia Ostrogskiego. Kondukty pogrzebowe kalwinistów, przechodzące koło kościoła św. Jana były często atakowane przez pospólstwo.

23 Ibidem, s. 38.

${ }^{24}$ LMAB, sygn. F 40/1024, s. 16-26 Relacja z rozprawy sądowej toczącej się w sprawie spalenia zboru wileńskiego 20 czerwca 1591 roku przez studentów akademii wileńskiej, m.in. Szczęsnemu Zborowskiemu, Janowi Kuczborskiemu i Wawrzyńcowi Kosmowskiemu. W odpisie zamieszczone relacje naocznych świadków podłożenia ognia w nocy z 10 na 11 czerwca (Niejaki Bartel Niemiec słyszał w jatce rzeźnickiej rozmowę jakiegoś mnicha z rzeźnikiem, w której mnich powiedział, że na kazaniu polecono modlić się do Boga, by zbór się spalił, Mikołajowa Węgrzynowa zeznała, że słyszała z okna jak studenci mówili, że siedem razy rzucano ogień zanim budynek się zajął). Zbór zapalił się od cegieł owiniętych szmatami i podpalonych. 
1611 (podłożenie ognia przez pospólstwo i uczniów akademii jezuickiej) ${ }^{25}$, 1639 (zamieszki wywołane przypadkowym ostrzelaniem przez szlachtę z łuku murów i figury św. Michała w kościele pod tym wezwaniem). Zbór ten mieścił się bowiem niemal naprzeciw klasztoru bernardynek i kościoła św. Michała. Zorganizowano przy nim wartownię i utrzymywano ośmiu strażników, którzy pilnowali budynku przed atakiem katolików ${ }^{26}$. Po wydarzeniach tumultu z lat 1639-1640 kalwiniści zmuszeni zostali w 1642 roku do budowy nowego kościoła poza murami miejskimi Wilna, lokując w nim wyposażenie z zamkniętego już w samym mieście budynku. Tu doświadczyli kolejnego zniszczenia swej nowej siedziby, co nastąpiło w 1655 i 1682 roku $^{27}$. Kościół jednak odbudowywano, także dzięki miejscowym luteranom,

25 Ibidem, s. 171, tu opis działań pospólstwa w 1611, które najpierw okradło, a potem podłożyło roku ogień pod zbór, szpital i szkołę, spaliło parkan i próby wrzucenia do ognia podwojewodziego Siesickiego, który próbował zapobiec działaniom tłumu. Synod z 1 lipca 1612 r. postanowił odbudować zbór. Zbór mniejszy, drewniany Odbudowano go w 1612 r. dzięki podatkowi przyjętemu przez reformowanych: 1 złotego od włóki (na szkołę) i 6 groszy polskich od chłopa. Dzięki składkom powstał mniejszy, drewniany budynek zborowy. Księży reformowanych zaczepiano na ulicach, czasem próbowano zabić, jak to np. podczas jednego z nabożeństw, gdzie do środka zboru wszedł student i próbował nożem zadać cios kaznodziei. W 1623 r. odnotowano skandaliczne zakłócenia nabożeństw przez studentów akademii wileńskiej.

26 B. Zwolski, op.cit., s. 11-14. W jednej z wersji zamieszki 6-7 października 1639 roku wywołali podochoceni alkoholem na chrzcinach kalwiniści, którzy ostrzelali z łuków figury kościelne, w drugiej, że strzały te padły w obronie budynku wobec tłumu, który odpowiednio wyposażony zgromadził się, aby rozebrać kalwińską świątynię, w trzeciej: podochoceni szlachcice (Rakowski i Piekarski) strzelali do kawek i strzały przypadkowo trafily w figurę św. Michała. Relacja w LMAB, sygn. F 40/1021, s. 2-3 oraz LMAB F 40/239, s. 191-196. Ostatnio najpełniej H. Wisner, Likwidacja zboru ewangelickiego w Wilnie w latach 1639-1646, [w:] Odrodzenie $i$ Reformacja w Polsce, XXXVII, 1993, s. 89-102. Tu autor wspomina o zabezpieczeniu biblioteki zborowej i wywiezieniem jej do Kiejdan.

${ }^{27}$ LMAB, sygn. F/40 1021, s. 12-13 (tu też relacje w sprawie niszczenia zboru rosieńskiego), B. Zwolski, op.cit., s. 62. Wyrokiem sądu królewskiego musiano zamknąć budynek zborowy, znieść szkołę i szpital, a nowy budynek wznieść na swoim cmentarzu za bramą Trocka. Nowy zbór z 1834 r. zbudowano naprzeciw rozebranego budynku z 1682 r. Zob. też Dziennik podróśy po Litwie i Żmudzi odbytej w 1856 roku przę D-ra Trypplina, t. 1, Wilno, 1858, s. 146-147. Tu autor wspomina ruinę starszej budowli widoczną naprzeciw nowego budynku. H. Merczyng, Wilno ewangelickie, Wilno 1925, s. 13-14 informuje o herbach Radziwiłłowskich, które miały chronić ten budynek. Zob. też J. Lukaszewicz, op.cit., s. 277. Tu autor opisuje zniszczenie zboru w 1682 r., kiedy to rozebrano budynek z cegły i drewna (czyli wzniesiony w technice zw. wtedy pruskim murem), rozkradziono dzwony i nagrob- 
którzy zbierali na ten cel pieniądze w Prusach Książęcych, i wspierali wysiłki gminy helweckiej ${ }^{28}$. A stary budynek pozostał od 1642 roku opuszczony, mimo iż ,już kilka razy próbowało papiestwo nam to miejsce zapłacić, aleśmy woleli na wieczne przeciwko nim świadectwo zostawić"29.

Jak wspomniano, za przykładem Mikołaja Radziwiłła Czarnego, na wyznanie helweckie przeszła większa część politycznych elit Wielkiego Księstwa Litewskiego ${ }^{30}$. Z tym procesem, który trwał zaledwie kilka lat, należy skorelować coraz liczniejsze powstawanie zborów kalwińskich na Litwie. Znajdowały się one na terenie kilku województw: wileńskiego, trockiego, inflanckiego, nowogrodzkiego, witebskiego, połockiego, mścisławskiego, mińskiego, smoleńskiego, żmudzkiego, brzesko-litewskiego i kurlandzkiego $^{31}$. Badacze reformacji wskazywali przede wszystkim na Żmudź jako aktywne centrum kalwinizmu rozciagnnięte między Kielmami Birżami a Kiejdanami (na Żmudzi) oraz na ziemie leżące w trójkącie między Wilnem, Nowogródkiem a Mińskiem (na Litwie) ${ }^{32}$. Ogólna liczba zborów helweckich wynosiła w różnych okresach XVI wieku blisko $200^{33}$, z czego w województwie wileńskim było ich 39, trockim 29, a żmudzkim 30.

ki, cmentarz zbezczeszczono. M. Kosman, Jednota litewska..., s. 33 pisze, że stary budynek w Wilnie istniał w 1663 roku, bo w nim odbyto synod kalwiński, bo ten z ul. Zawalnej był zniszczony podczas potopu szwedzkiego.

28 G. Rhode, Brandenburg-Preußen und die Protestanten in Polen 1640-1740, Leipzig 1941, s. $55-58$.

29 Zbiór pomnikón reformacyi..., s. 39.

30 LMAB, sygn. F 40/239, Krótki rys historji zboru wileńskiego ew. reformowanego, s. 23-30. Tu passus o autorytecie Radziwiłłów na Litwie i o szybkim, aczkolwiek powierzchownym przez to rozpowszechnianiu się religii reformowanej, przechodzeniu na to wyznanie włościan w dobrach radziwiłłowskich. Gdy pierwsze nabożeństwa odbywały się w pałacu Radziwiłłów naprzeciw kościoła św. Jana, w kościele św. Anny kazania luterańskie głosił kaznodzieja Wiklef.

31 H. Merczyng, op.cit., mapa opracowana przez autora pokazuje lokację poszczególnych zborów reformowanych i ich przewagę liczebną nad kościołami luterańskimi. St. Tworek do podanych przez Merczynga 191 zborów dodaje jeszcze te w Brzostowicy, Dowspudzie, Szawlach, Siadach, Szawkianach, Oranach i Kurszanach, zob. St. Tworek, Z zagadnień liczebności z̧borów kalwiniskich na Litwie, w: Odrodz̧enie i Reformacja w Polsce, t. 17, 1972, s. 211.

32 K. Chodynicki, op.cit., s. 57.

33 W źródle LMAB, sygn. F 40/285, s. 1-2 zestawienie zborów reformowanych na Litwie w latach 1611-1654 w liczbie 113 budynków. Zestawienie zborów publikuje St. Tworek, op.cit., s. 213-214. 
Nieco mniej, bo w województwie nowogródzkim funkcjonowało ich 27. Niestety, ustalenie ich dokładnej liczby nie jest możliwe z racji braku pewnych wiadomości na temat ich funkcjonowania. Wiadomo, że liczba zborów systematycznie spadała, w czasach potopu szwedzkiego wynosząc około 140 budynków, na przełomie XVII i XVIII wieku osiagając liczbę 50, a pod koniec epoki nowożytnej wynosząc zaledwie 40 budowli i choć w porównaniu z Koroną była to i tak duża ilość, to ich spadek na Litwie był naprawdę znaczący ${ }^{34}$. Wiele $z$ nich, wznoszonych $z$ drewna wymagało pilnej interwencji budowlanej ${ }^{35}$. Pozycja kalwinistów w pejzażu religijnym i politycznym Litwy była już tylko wspomnieniem ich potęgi z XVI wieku.

Ścisłe powiązanie kalwinizmu z magnaterią miało i swe niekorzystne strony, ponieważ w przypadku konwersji magnatów skutkowało zwycięstwem katolicyzmu i przekształcaniem zborów (zwanych przez katolików kryplami) w kościoły katolickie ${ }^{36}$. Część zborów przechodziła w ręce ariańskie (np. za sprawą rodu Kiszków), jak zbory w Brześciu Litewskim, Białej, Mordach i w Losku, w którym zatrudniono jako kaznodzieję socynianina Szymona Budnego. W pojęciu miejscowej szlachty zbór był jej osobistą własnością, więc rezerwowała ona sobie prawo do jego zamknięcia i usunięcia heretyckiego kaznodziei w wypadku zmiany swego wyznania. Przykładowo przejście na katolicyzm kasztelana połockiego Mikołaja Zenowicza skutkowało utrata zborów w Smorgoniach i Głębokiem, prokatolickie sym-

34 Szerzej patrz: ibidem, s. 207.

35 H. Merczyng, op.cit., s. 16 oraz 83-104, gdzie zestawiono wiadomości na temat 190 zborów helweckich na Litwie. Często nie można dokładnie określić ilości zborów reformowanych, bowiem część z nich przez badaczy brana jest za kościoły luterańskie, zob. T. Kempa, Luteranie..., s. 110. Autor mówi o niejednoznacznym konfesyjnym określeniu świątyń protestanckich, takich jak te w Birżynianach, Retowie i Płotelach. Zestawienie zborów publikuje W. Krasiński, op.cit., s. 208-228, zob. też M. Kosman, Reformacja i kontrreformacja..., s. 52-54. J. Lukaszewicz, op.cit., s. 289-297 (tu omówiona utrata zborów w czasach Jana Kazimierza i saskich). Łukaszewicz w cz. II zestawia zbory helweckie i ich dzieje, patrz J. Łukaszewicz, op.cit., cz. II, s. 6 i nast., ostatnio najpełniej W. Kriegseisen, Ewangelicy polscy i litewscy w epoce saskiej, Warszawa 1996, s. 100-107; G. Błaszczyk, Żmudź w XVII i XVIII wieku. Zaludnienie i struktura spotecæna, Poznań 1985, s. 84-85; W. Kriegseisen, Ewangelicy..., s. 118-119 i M. Kosman, Litewska..., s. 40.

36 Przykładowo Stanisław Radziwiłł, syn Mikołaja Radziwiłła Czarnego usunął ministrów kalwińskich m.in. ze zboru w Ołyce, Lukiszki podarował jezuitom, Lew Sapieha odzyskał zbory w Ikaźni i Orszy, zob. J. Łukaszewicz, op.cit., s. 45 i 157. 
patie Aleksandra Chodkiewicza zaowocowały oddaniem katolikom zborów w Szkłowie i w Giałowie, a zmiana wyznania przez wojewodę mińskiego Aleksandra Słuszkę skończyła się upadkiem zboru w Tajmanowie ${ }^{37}$.

Z kolei kalwinizm wspominanych już tu często Mikołaja Radziwiłła zw. Czarnym ${ }^{38}$ i Mikołaja Radziwiłła zw. Rudym ${ }^{39}$ zapewniły trwałość służby kalwińskiej parafiom i budynkom znajdujących się np. w dobrach birżańskich ${ }^{40}$. Większość zborów była zakładana przez patronów, jakimi była szlachta, właściciele miasteczek i wsi. Oni zabezpieczali przez wieczyste legaty finansowo utrzymanie kaznodziei i budynku zboru. Marcin Szwab tak zabezpieczył Szwabiszki a kniaź Jan Jan Świerski zbór w Świranach ${ }^{41}$. Funkcjonowanie zborów ułatwiały przede wszystkim legaty i nadań w postaci niewielkich majątków ziemskich, przykładowo zbór w Birżach otrzymał w grudniu 1592 roku wsie Mstuny i Szołondy ${ }^{42}$. Zofia Wnuczkowa wykupiła i przekazała zborowi Szydłów, by zachować tamtejszy zbór, który „od lat kilkadziesiąt z Rzymskiego bałwochwalstwa czyszczony i ochędożony” jest. Zbór w Serejach utrzymywany był przez okoliczne majątki Nargiele i Sakowiszki przekazujące m.in. żywność kaznodziei ${ }^{43}$. Fundator zboru w Dziewałtowie, marszałek bracławski Jerzy Samson Podbereski zapisał na rzecz kościoła wieś Kirmuż i fundusz w wysokości 13500 złotych $^{44}$.

37 W. Krasiński, op.cit., s. 210-224; J. Lukaszewicz, op.cit., s. 31.

38 W 1557 roku ufundował w Wilnie pierwszy na Litwie kościół (zbór) i szkołę wyznania reformowanego. Wkrótce zaczął energicznie zwalczać katolicyzm i prawosławie w swoich litewskich i małopolskich posiadłościach: od 1560 odebrał katolikom kościoły w Nieświeżu, Klecku, Ołyce, Subotnikach, Mordach i Szydłowcu i przekazał je pastorom kalwińskim. LMAB, sygn. F 40/239, Krótki rys historji z̧boru wileńskiego ew. reformowanego, s. 17. W tekście autor gloryfikuje Mikołaja Czarnego, twierdząc, że jego wyznanie kalwińskie wynikało z wierności Słowu Bożemu, a nie z opozycji w stosunku do Kościoła katolickiego, czy mody wśród magnaterii, też PSB, inne

39 LMAB, sygn. F 40/239, Krótki rys historji ̨̧oru wileńskiego ew. reformowanego, s. 17-18. W 1564 przeszedł na kalwinizm i stał się przywódcą ruchu różnowierczego w Wielkim Księstwie Litewskim, zakładał zbory, sprowadzał z zagranicy uczonych protestanckich i założył w Birżach wyższą szkolę dla młodzieży kalwińskiej.

40 H. Merczyng, op.cit., s. 8-9.

${ }^{41}$ Akta synodów prowincjonalnych..., op.cit., s. IX.

42 W. Krasiński, op.cit., s. 208; Zbiór pomnikón reformacyi..., s. 136.

43 Zbiór pomnikón reformacyi..., s. 137 i 177-178.

44 W. Krasiński, op.cit., s. 210-220. 
W wielu przypadkach borykano się z kłopotami finansowymi, jakich przysparzało zbytnie uzależnienie się parafii od fundatora, często duchowni musieli się długo upominać o należne uposażenie, czego przykładem jest sytuacja ministra zboru w Rohozinie. Z kolei zbór w Szydłowie cieszył się lepszą sytuacją finansową gdyż rodziny Wnucznków, Grużewskich i Zawiszów przekazywały systematycznie stosowne legaty na jego utrzymanie. Większą niezależnością finansową cieszyły się zbory miejskie leżące w Wilnie, Mińsku czy Nowogródku, ponieważ źródłem ich utrzymania były nie tylko darowizny szlachty, ale również mieszczańskie składki. Status finansowy był w wypadku Wilna dużo lepszy, mimo iż koszty jego utrzymania podnosiło utrzymanie przytułku i straży, która starała się zbrojnie chronić zbór wileński, wykorzystując nawet ofiarowane w tym celu armaty ${ }^{45}$.

Pierwsze nabożeństwa odbywały się, jak już wiadomo, w kamienicach wileńskich, w Brześciu Litewskim czy w Mińsku ${ }^{46}$. Potem zbory powstawały w miastach rezydencjonalnych, takich jak Kiejdany, Birże i Słuck oraz w dobrach rodzinnych jak w Dubinki, Owanta i Wiżuny ${ }^{47}$. W miastach zazwyczaj budowano zupełnie nowe budynki, rezygnując z przejmowania kościołów katolickich. Taka sytuacja miała miejsce poza miastami, gdzie wraz z przejściem na kalwinizm szlachcic usuwał księdza, instalował kalwińskiego ministra zgodnie z zasadą cuius regio eius religio, a z kościoła czynił zbór, dbając, by zborownicy nie chodzili na nabożeństwa do świątyń innych wy$z_{n} n^{48}$. Ale i w dobrach ziemskich wznoszono wiele nowych budynków dla tworzonych gmin helweckich. Budowano je zazwyczaj z dwóch rodzajów budulca. Najczęściej były to budynki szachulcowe (Orla, Sołomieście) lub drewniane, na kamiennej podmurówce, które mogły ulec najłatwiejszemu zniszczeniu, ale ze względu na obfitość lasów, łatwiej można było je naprawić lub odbudować. W grupie tej umieścić można zbory w Bielicy, Bolsie, Poszuszwiu, Retowie, Szwabiszkach, Słomomieście, Kopysi, Rossieniach czy

45 Akta synodów prowincjonalnych..., s. IX-X, W. Krasiński, op.cit., s. 223.

46 W. Krasiński, op.cit., s. 208, J. Lukaszewicz, op.cit., cz. 2, s. 11.

47 U. Augustyniak, op.cit., s. 227.

48 M. Kosman, Litewska Jednota...., s. 14. 
w Bojnarowie ${ }^{49}$. Budowle kamienne i ceglano-kamienne były mniej popularne, ale oczywiście bardziej prestiżowe. Do tej grupy należy zaliczyć późnogotyckie, renesansowe i barokowe w swej stylistyce zbory w Dziewałtowie, Greżach, Wilnie, Kiejdanach, Kojdanowie, Rykontach, Smorgoniach ${ }^{50}$, Szydłowie (zbudowanym na miejscu wcześniejszego kościoła drewnianego) ${ }^{51}$, Mińsku (gdzie zbór zorganizowany w kamienicy przekazanej przez Hieronima Żymeńskiego przetrwał do ok. 1703 roku), Głębokim (zbór wystawiony na koszt wojewody brzeskiego Krzysztofa Zenowicza) i w Kielmach, w których kościół w stanął na koszt żmudzkiego sędziego ziemskiego Jerzego Grużewskiego (w 1615 lub w 1622 roku).

Inwentarze wspominają o kryciu budynków zborowych czerwoną dachówką lub czerwonym gontem, a blachą kopuł (bani) na wieżach, zwieńczonych krzyżami. Jak wskazują zachowane do dziś przykłady budownictwa, najczęściej były to budynki jednoprzestrzenne, z mniej lub bardziej zaakcentowanym prezbiterium, z przedsionkiem zwanym babińcem, oświetlone oknami (w liczbie od 4 do 10). Co ważne, budynki kościelne były w większości budowlami obronnymi, z masywnymi wieżami (z dostępem z empory, jak w Ostaszynie i Kojdanowie), otaczane murami z basztami narożnymi i wzmocnionymi podwójnymi drzwiami. Ich stylistyka zazwyczaj wykazywała ścisłe związki z budowlami średniowiecznymi, które z natury swej miały obronny charakter. Zbór w Kojdanowie otaczał mur z dziewięcioma basztami z których dwie miały połączenie z domem kaznodziei, a całość otaczała fosa z dwoma bramami. Zbór w Dubinkach, w którym legł na wieczność Mikołaj Radziwiłł Czarny, wzniesiono na jeziornej wyspie, a dostępu do niej bronił łatwy do zerwania drewniany most ${ }^{52}$. Kiejdanom spokój zapewniało 1800 mieszkańców podzielonych na cztery pułki i dodatkowo specjalna milicja ${ }^{53}$.

49 Zbiór pomnikón reformacyi..., s. 98. Tu zastrzeżono drewno na odbudowę i naprawę budynku pochodzące z okolicznych lasów. W. Krasiński, op.cit., s. 220. Przykładowo o kościele kopyskim w 1850 r. pisano, że to kościół drewniany, bardzo stary, z wieża, w złym stanie, wymagający nowego dachu i oszalowania, wewnątrz brakowało podłogi. Należało też wyremontować wieżę i organy, zob. LMAB, sygn. F 40/514, s. 23.

${ }^{50}$ W. Krasiński, op.cit., s. 212.

51 Zbiór pomnikón reformacyi..., s. 138. Zapis na budowę murowanego zboru wyniósł 500 kop groszy.

52 U. Augustyniak, op.cit., s. 228-229.

53 M. Kosman, Jednota litewska..., s. 17. 
Wiadomości o ruchomym wyposażeniu kościołów kalwińskich pochodzą z różnych źródeł. Najczęściej są to zapisy inwentarzowe, zapisy testamentowe, choć zdarzają się też protokoły zeznań sądowych, w których wspomina się o zniszczeniach w kościele dokonanych przez podpalaczy. Jak wynika np. z takich zeznań dotyczących zboru wileńskiego zniszczonego podpaleniem w 1591 roku, budynek ten miał wieżę z górną, drewnianą kondygnacja. Jego korpus oraz filary zbudowano z cegły, zapewne przesklepiono i nakryto drewnianym dachem. Ogień, który wzniecono, zniszczył zegar i nadtopił jego mechanizmy, stopił dzwon główny i zegarowy oraz zniszczył ustawioną wewnątrz kazalnicę i ławki ${ }^{54}$. Wnętrza, szczególnie te w budynkach murowanych, były raczej surowe i pozbawione ozdób figuralnych, ale wypełnione za to kolorowymi sprzętami. Pierwszym przykładem takiej surowości jest kaplica w wileńskim pałacu Radziwiłłów, która mogła być dekorowana ornamentalnie, ściany zasłonięte były czarną materią, a na ścianie widniał tylko biały, kontrastujący krzyż ${ }^{55}$. O prostocie wnętrz przekonuja nas także zachowana ikonografia wnętrz kościołów helweckich, takich jak ta z Kielm czy Dziewałtowa.

Wyposażenie poszczególnych zborów różniło się między sobą jakością wykonania, ponieważ inaczej wyglądały zbory główne, takie jak ten wileński, kojdanowski czy birżański, w których spotykali się magnaci i bogate mieszczaństwo, a inaczej wyglądały zbory wznoszone dla chłopstwa. Te największe były oczywiście najbogaciej dekorowane, starano się o fundację złoconych lub polichromowanych sprzętów, używano drogich tkanin, wnętrza oświetlano kosztownymi żyrandolami. Śpiewom podczas nabożeństwa towarzyszyły dźwięki instrumentów organowych bądź kapeli książęcej (prowadzonej m.in. przez Cypriana Bazylika czy Wincentego z Szamotuł). Zbory chłopskie nie mogły pozwolić sobie na bogatsze wyposażenie, ograniczano się więc do wykonania niezbędnych sprzętów o prostej stolarskiej formie, które skromnie polichromowano lub zwyczajnie pokostowano ${ }^{56}$.

\footnotetext{
54 Zbiór pomnikón reformacyi..., s. 60.

55 Ak.ta synodów prowincjonalnych..., s. XVII.

56 LMAB, sygn. F 40/91, Akta z̧boru w Stucku, s. 73. Według opisu ambonę z baldachimem, z drewna sosnowego, wykonał snycerz i pomalował ją na srebrno i złoto. Chór wsparto na 4 słupach, a jego front pomalowano na srebrno i złoto, ozdobiono nieznanymi rzeźbami (ornamentami?) i pokostowano. Słupy podtrzymujące pomalowano do połowy
} 
Inwentarze zboru wileńskiego z 1711 roku (zwanego w XVIII wieku szopq ze względu na skromną formę i brak wieży), spisane po zniszczeniach potopu szwedzkiego mówią o umieszczonym za przegrodą czerwonym stole Wieczerzy Pańskiej, zdobionym rzeźbą, złoceniami i oraz inskrypcjami zaczerpniętymi z Pisma Świętego, którego wersety umieszczono równocześnie obok na ścianie. Inskrypcje zdobiły ściany ambony, czyli katedry, obok której ustawiono klepsydrę, ,alias zegarek szklany z piaskiem wyciekające mający" oraz ławki i pomalowaną na zielono kratę. Posadzkę wyłożono cegłami a wnętrze oświetlono srebrzonym lichtarzem $z$ drewna i blachy ${ }^{57}$.

Bogactwo wyposażenia innych reprezentacyjnych kościołów kalwińskich prezentują inwentarze zborów kielmeńskiego ${ }^{58}$ i kojdanowskiego, wzniesionego na kopcu gasztołdowskim, który w 1794 roku wymienia wykonany piękną robotą stolarską stół Wieczerzy Pańskiej. Położono na nim malowany na zielono i żółto pulpit na Biblię brzeska, zapisując: „Na tymże Stole Pańskim, na Pulpicie Biblia Święta Edycyi Brzeskiej (...), oprawiona w Skurkę czerwona; na Oprawie z Obu stron w Srzodku, Sztuczki dwie wyzłacane z Herbami Xsiążąt Radziwiłłów, a na iedney z Nich te wokoło Litery: I.R.M.D.K.W.X.P.S.B.X.. Narożników odlewanych y pozłacanych Osm, Sztuczek cztery takich od Klauzurek, Oszyta Skureczką szarą". Wnętrze tego kościoła oświetlono dużym mosiężnym świecznikiem z krzyżem, 10 lichtarzami ściennymi oraz dwunastoma świecznikami. Ławki pomalowano na biało i niebiesko, a ławę kolatorską obito suknem. Na ścianach zwieszono dwie duże czarne tablice do pisania psalmów, a obok stołu, po

na biało, podobnie jak stół Wieczerzy Pańskiej. Na nim ustawiono pulpit obity skóra, na którym leżała Biblia brzeska. Sprawa wieży wymaga wyjaśnień, ponieważ budynek jej nie miał, planowano ją zbudować w 1719 roku po uzyskaniu pozwolenia od miejscowego biskupa. Wynika z tego, że publikowany np. w Zbiór pomników reformacyi..., s. 195 rysunek zboru wg Jana Cedrowskiego pokazuje kościół już po wzniesieniu wieży. W 1731 r. biskup wytoczył proces ludwisarzowi i fundatorowi dzwonu, co może wskazywać, że ante quem powstała wieża, zob. W. Gisbert-Studnicki, op.cit., s. 60-61. Wcześniej dzwon umieszony był na stojącej obok dzwonnicy (napis na dzwonie z 1611 roku cytuje H. Merczyng). H. Merczyng rysunek Cedrowskiego umieszcza jako ilustrację przy omawianiu zboru luterańskiego, a W. Kriegseisen podpisuje go jako zbór reformowany, zob. H. Merczyng, Wilno ewangelickie, Wilno 1925, s. 8, W. Kriegseisen, op.cit., s. 102.

57 W. Gisbert-Studnicki, Kościót ewangelicko-reformowany w Wilnie, Wilno 1935, s. 28-29.

58 K. Grużewski, Kościót ewangelicko-reformowany w Kielmach, Warszawa 1912, s. 167-168. 
lewej wzniesiono malowaną na „kafofo” sześcioboczną ambonę z dekoracjami snycerskimi. Przy stole komunijnym stanęła biało-niebieska szafa na naczynia liturgiczne i ława zwana Ksiazzęca. Na emporze wzniesiono pięciogłosowy pozytyw z cynowymi piszczałkami ${ }^{59}$.

Najważniejszym sprzętem w każdym zborze była przede wszystkim kazalnica (zw. katedra), z której wygłaszano do wiernych kazanie (przy fundacji niemal każdego zboru pojawiało się przecież stwierdzenie, że zbór ma służyć przepowiadaniu słowa Bożego). Był to kulminacyjny i najważniejszy element nabożeństwa, skoro w Nowym Mieście na Żmudzi za jego opuszczenie można było zapłacić na szpital karę w wysokości od 1 do 4 groszy lub posiedzieć jeden dzień (dla opornych) „w kunie” znajdującej się przy kościele $^{60}$. Drugim niezbędnym elementem wyposażenia był stół służący spożywaniu Wieczerzy Pańskiej. Jego znaczenie wraz z kazalnica najlepiej wyraził Janusz Radziwiłł, pisząc: „umyśliłem w mieście moim słuckim fundować Zbór Ewangelicki ku chwale Bożej dla przepowiadania Y słuchania

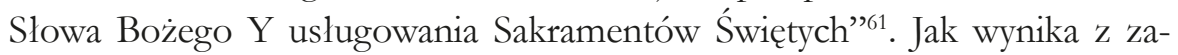
chowanych dokumentów, ten sam Janusz Radziwiłł zalecając naprawę zboru w Birżach, dokładnie określili, jak ma wyglądać jego wnętrze: „Naprzód Stół Pański kazać zrobić piękną stolarską robotą czworograniasty nie mały, pod nim pomost o trzech stopniach, w koło kratę albo Balasy, Sam Stół nakryć Aksamitem Czyrwonym z Frenzlą złotą y z Ząbkami po Węgłach złotymi. [...] Formy po lewey stronie w Kościół wszedłszy, takież i iako po prawej, które iuż robić poczęto, aby iako naprędzey postawiono. A w przedniey Formie, aby dla żony mey tak zrobiono jakom rozkazał. [...]. Przy Catedrze Formę pojedynkową dla Ministra zrobić [...]. A velum aby z iednego szło y na wschodek y nad Catedra dla lepszey resonanty głosu na kazaniu [...]. Odrzwie też dać insze dać zrobić dębowe, taką robotą iako okna w kamienicy na których napisać od kogo z kiedy ten Zbór zbudowany".

59 LMAB, sygn. F 40/69/1, Inwentarz z̧boru w Kojdanowie, s. 15 v., K. Grużewski, op.cit., s. 168 .

${ }^{60}$ Zbiór pomnikón reformacyi..., s. 92.

${ }^{61}$ LMAB, sygn. F 40/91, Akta z̧boru w Stucku, s. 4-9 dokument fundacyjny Janusza Radziwiłła: zbór i plebanię miał na polecenie księcia zbudować stolnik miński i starosta słucki Jerzy Kapaszczewski, wykorzystując drewno z książęcych lasów. 
Wystrój tego wnętrza pozbawiony był dekoracji ornamentalnych i figuralnych, bowiem fundator przypomina tylko o wykonaniu we wnętrzu powłok malarskich oraz informuje, by „Kathedrę, Formy wszystkie, Ganek y Drzwi żółto kazać pokościć”. W zborze w Wiżunach („,Zbór sam aby był porządnie wewnątrz y zwierzchu opatrzony postrzec tego tudziesz aby Cathedra, Formy y insze ochędostwa pięknie y porządnie sporządzone były)" nad grobem zmarłego w 1604 roku ojca, Krzysztofa Radziwiłła „Pioruna” Janusz Radziwiłł kazał powiesić „do czasu Tablicę drzewnianą Robotą cudną farbami należnemi i ozdobioną na ścianie przybić s tym Nagrobkiem, który Emilius Portus professor Heydelberski napisał, takąż drugą iedno mniejszą nad Synem moim Mikołaiem z Nagrobkiem, który tamże P. Rybiński proszę aby napisał”. Strona estetyczna wnętrza była bardzo ważna, ponieważ Radziwiłł życzył sobie, by w Zabłudowie „Formy aby we wszytkim Zborze iednakowe były iako w Kolorze, tak y wszędzie wtąż y Cathedra. Stół też Pański aby był chędogi y chędogo postawiony” "2.

Wyposażenie każdego zboru uzupełniały ławki (zwane formami) ustawiane $\mathrm{w}$ nawie zboru oraz na emporach (zwanych gankami), które wznoszono w korpusie od strony zachodniej. Dla opiekuna zboru (jak np. w Kiejdanach dla Radziwiłłów) w części prezbiterium ustawiano osobną ławę kolatorska, w pobliżu znajdowała się drewniana, cynowa albo nawet srebrna chrzcielnica ${ }^{63}$. Odnotowano czarne tablice, na których wypisane złotymi literami:" Credo, Oyczenasz, Przykazania, Ustawa Chrztu y S. Wieczerzy P.’64.

Złotnictwo, czyli tzw. aparaty w zborach kalwińskich nie było zbyt liczne, choć stanowiło ważny element wyposażenia. Do spożycia pamiątki Wieczerzy Pańskiej używano najczęściej jednego kielicha, do którego wi-

${ }^{62}$ Akta synodów prowincjonalnych..., s. XVII-XXIV. W tekście inne wskazówki co do utrzymania zborów w Popiele, Nowym Mieście, Wiżunach, Owancie i Owińskach, Bielicy oraz zborów lubeckiego i wsielubskiego.

${ }^{63}$ W zborze w Kojdanowie odnotowano duża, okragła chrzcielnicę fundacji V. D. z data 1741 oraz inskrypcja , "Ite in uniwersum mundur et baptizae”, LMAB, sygn. F 40/69/1, Inwentarz zboru w Kojdanowie, s. 24, LMAB, sygn. F 40/892, Archiwalia zboru stuckiego 1642-1883 , s. 55. W zestawieniu wydatków z 1745-1746 za planowano wykupić „chrzcielnicę srebrną zastawioną u Imć. X. Benkiena Kazn. Słuck. Aug. Conf. deklarował Imć Stanisław Olendzki Starosta Dziakowski”.

${ }^{64}$ LMAB, sygn. F 40/91, Akta z̧oru w Stucku, s. 73, U. Augustyniak, op.cit., s. 230. 
no nalewano ze specjalnej konwii, pateny lub ozdobnego talerza. O zasobach naczyń, podobnie jak w przypadku meblarstwa informuja nas zapisy testamentowe i przede wszystkim inwentarze. Najczęściej mają one ogólny charakter, jak ten informujące, że w kościele w Żejmach, ufundowano wykonany ze srebra kielich, misę oraz konewkę ${ }^{65}$, albo że znajdujące się w kościele w Brześciu litewskim srebra przeniesiono po utracie zboru do Nurca i Litwonowy, a gdy upadł Nurzec, trafiły do Szabelina ${ }^{66}$. Jak wyglądało złotnictwo w znaczących zborach, możemy się przekonać na podstawie inwentarzy Słucka ${ }^{67}$ czy Kojdanowa opisującego duże kielichy z patenami oraz konwie do wina. Jedną z nich zdobiła inskrypcja: „Ta konewka umyślnie robiona ku Usłudze Stołu Bożego aby z niey Usługowanie Testamentowi Syna Bożego. Aby się tey nikt nie ważył ku pożytkowi swemu inszemu obracać a ieśliby się kto śmiał ważyć wzniąć Ią od Stołu Bożego niech dobie wszystko nieszczęście Domu y Potorastwa wezmie y Trąd Naamanow niech on w Domu iego zostanie na wieki, w Biblij napisano" ${ }^{\text {. }}$.

65 Zbiór pomnikón reformacyi..., s. 154.

${ }_{66}$ W. Krasiński, op.cit., s. 209, LMAB, sygn. F 40/95, Nurzec, s. 1 i nast. Fundatorem kościoła w Nurcu z 1638 roku był Piotr Benedyktowicz Kochlewski, wznosząc zbór z wieżą, dwoma dzwonami i zegarem oraz plebanię. W 1760 r. aparaty przeniesiono z kościoła nurzeckiego do szabelińskiego, w a 1766 roku do Szabelina przeniesiono dzwony. Według inwentarza z 1741 r. złotnictwo reprezentowały dwa lichtarze cynowe, cynowa chrzcielnica, srebrny kielich ze złoconymi brzegami z inskrypcja „bibite ex hoc omnes”, srebrna i patena flasza, tuwalnie, obrusy i pięć chust do nakrywania kielicha.

67 LMAB, sygn. F 40/91, Akta zboru w Stucku, s. 69 inwentarz złotnictwa z 1849 roku wymienia: konew chrzcielna: „Ego vos baptizo. Adua ssed in medio vestri consistit qui vos baptizavit spiritus S. et igne", oraz kielich z sześcioma herbami: 1 orzeł jednogłowy z tarczą podzieloną na cztery herby; 2 gwiazda nad półksiężycem, 3 łódź, 4 orzeł jednogłowy, 5 trzy rzeki, 6 trzy trąby.

${ }^{68}$ Inwentarz na s. 17-21 wymienia dwie duże pateny, w tym jedna z herbem Radziwiłłów i literami „IR”, oraz konewkę do chrztu fundacji Teodory ze Stryjeńskich Grabowskiej z 1749 r. Prócz tego zapisano Duzy kielich „Kubek błogosławienia, którym błogosławiemy izali nie jest społecznością Krwie Krystusowey”, z herbem Ryby i literami A.S., do tego kielicha przypisana była konewka oraz patena z literami Z.C.K.J.C z inskrypcja „1 Cor. 10 Chleb który łamiemy izali nie iest społecznością Ciała Krystusowego”. Do komunii chorych używano małego drewnianego, toczonego kielicha z napisem: „Donacja Jana i Heleny z Siemigrodzkich, Miłosnickich” z 1785 r. Wśród tkanin zapisano nakrycia na stół komunijny, obrus holenderski, holenderskie tuwalnie, chustki do nakrycia kielicha, konewki i pateny z napisami haftowanymi: „W Krystusie mieszka Zupełność Bostwa cieleśnie”, „Pan Iezus mówi: Iam iest on Chleb Żywota, Kto do mnie przyjdzie nie będzie łaknął. A kto 
Ważnym elementem wyposażenia były zegary wieżowe i dzwony, których dźwięk sygnalizował wszystkim mieszkańcom, bez względu na wyznanie, odbywające się w miejscowości różne uroczystości. Dzwony odnotowano w inwentarzu Kojdanowa ${ }^{69}$ i Słucka $^{70}$ w kolejnym wspominano dzwon na wieży kościoła w Żejmach, a dwa na leżących obok cmentarzu ${ }^{71}$. A że ich odlanie było drogie, więc księża katoliccy chętnie je rekwirowali, najczęściej bezpośrednio przez podpaleniem kościoła. Taka sytuacja miała miejsce we wspomnianych wyżej Lubeczu czy w Orłowie, gdzie ks. Wanowski spalił zbór, zabierając z niego wcześniej dzwon. W 1725 roku biskup łucki Rupniewski zabrał nowy dzwon ze zboru w Orli. Czasem za fundację dzwonu można się było nabawić kłopotów ze strony hierarchii katolickiej, jak w przypadku zboru Wilińskiego, w którym dzwon ufundował w 1731 roku chorąży starodubowski, Michał Wołk-Łaniewski. Biskup wytoczył za to proces jemu, ludwisarzowi i ministrom kościoła ${ }^{72}$.

Zbory kalwińskie pełniły funkcje miejsc pochówkowych dla najznamienitszych kalwinistów. Ich ciała składano najczęściej w kaplicach dobudowywanych do kościołów albo wzniesionych jako samodzielne budynki stojące obok korpusów budynku ${ }^{73}$. Zmarłych składano w piwnicach zwanych powszechnie sklepami (jak w Kielmach), a w nawie ustawiano stosowne po-

wierzy we mnie nie będzie pragnął na wieki. Ioan Cap VI” oraz „Błogosławieni którzy łakną y pragna sprawiedliwości abowiem takowi nasyceni będa. Mat V. Kto pożywa Ciała mego y pije Krew moię ma Zywot wieczny a ia go wzbudzę w On dzień Ostateczny. Duchci iest który Obzywia, Ciało niec niepomaga. Johan V.”. Zob. też S. Klaczyński, Zabytki reformacyjne $w$ Wilnie, Wilno 1926, s. 8.

${ }^{69}$ LMAB F 40/69/1, Inwentarz, zboru w Kojdanowie, s. 16-16 v. Na wieży zawieszono dwa dzwony: jeden duży fundacji Teodory ze Stryieńskich Grabowskiej Starościny Wisztynieckiej z 9 maja 1728 r. oraz drugi, mniejszy, nieznanego fundatora (T. Grabowskiej?) odlany przez Andreasa Derlinga.

70 LMAB, sygn. F 40/91, Akta źboru w Stucku, s. 42-43. Wymieniona drewniana dzwonnica, oraz trzy dzwony: jeden duży, drugi z powodu pęknięcia przelany w Urzeczu, trzeci mały, fundacji X. Michała Katyszy (?).

71 Zbiór pomnikón reformacyi..., op.cit., s. 155.

72 W. Krasiński, op.cit., s. 217, M. Kosman, Litewska jednota..., s. 117.

73 Przy zborze wileński znajdowały się grobowe pomniki marmurowe oraz kaplice rodziny Schretterów, zob. M. Kosman, Reformacja i kontrreformacja..., s. 60. Podczas pogromu kalwinów w 1682 r. w sklepach (piwnicach) ukryli się duchowni tego wyznania, zob. J. Lukaszewicz, op.cit., s. 277. 
mniki grobowe. Takim pomnikiem upamiętniony został Mikołaj Radziwiłł Czarny, który zmarł 28 maja 1565 roku i spoczął najpierw w Wilnie, a po przeniesieniu pochowano go w zborze w Dubinkach, przy Mikołaju Rudym. Jego żona Elżbieta Szydłowiecka zmarła w 1562 roku i została pochowana w zborze w Żakiszkach, co również odpowiednio upamiętniono ${ }^{74}$. W Hneznej koło Izabelina pogrzebano kasztelanową wileńską Krystynę Chodkiewicz, w Kiejdanach spoczęli Krzysztof i Janusz Radziwiłłowie, a w sklepie zboru świrańskiego złożono ciało kniazia Bolesławowicza Swirskiego, marszałka królewskiego ${ }^{75}$.

Pochówki organizowano oczywiście zgodnie z barokowa pompa funebris, o czym świadczą fragmenty katafalku odnotowane w zborze w Słucku ${ }^{76}$ oraz w Kojdanowie, gdzie przechowywano fragmenty ozdobnego castrum doloris. We wnętrzu, na ścianach tego samego budynku zawieszono herby Grabowskich, Stryieńskich, Oborskich, Grużewskich i Mackiewiczów oraz blachy z herbami, inicjałami i z datami narodzin i śmierci. Jadwigę Monkównę Gabrielową Kiersnowska, podczaszynę starodubowską upamiętniono pomalowanym na czarno płótnem, na którym umieszczono wykonaną białą farba inskrypcję ${ }^{77}$. Zbory kalwińskie pełniły jeszcze inna, ciekawą funkcję. W nich odbywano pokutę za popełnione zło, były też świadkiem dokony-

74 W. Krasiński, op.cit., s. 190, 211-212, B. Grużewski, op.cit., s. 168. Tu autor opisuje pochówki w krypcie zboru w Kielmach.

75 Akta synodów prowincjonalnych..., s. 79.

76 LMAB, sygn. F 40/91, Akta zboru w Stucku, s. 42.

77 LMAB F40/69-1, s. 26-26 v: pozostałości po pogrzebie Teodory ze Stryjeńskich z 1763 roku: „Geniuszów rzniętych robotą snycerska, wyzłacanych; Dwa z Nich wyrażaią Rycerzow Uzbroionych, ieden z nich: Stan Duchowny; ieden zaś: Stan Ubogich [...]. „Geniuszow wyrzniętych z tarczyc, z skrzydłami rozpiętymi, malowanych, trzymaiących niegdyś Portret W: Starościney nad Katafalkiem. Kolumny z tarczyc wyrzynane z Koronami, malowane rożnymi Farbami, na których Herby rozne Domow Wielkich skoligowanych z Domem Grabowskich; pod Herbami na Postumentach, na Kolumnie pierwszej wyrażono: Ogród, Pałac ettc. a nad niemi: W obłokach duże Ręce trzymaiące Koronę w Wianku z Kwiatów, y z tym napisem u dołu Calo kontenta tenri. Na kolumnie drugiey wyrażono Klapsydrę z dwoma skrzydłami, a pod Oną na Ziemi: Krzyże dwa z Księżycem powalone y połamane (:to iest Herb IM Stryieńskich:) a u dołu napisano: Colligit hora Cruces. Na kolumnie trzeciey Herb Stryieńskich to iest Krzyż z prawey strony u dołu Księżyc z napisem u dołu: Crix Lunaq Divum. A na czwartey Kolumnie: Piramida prosto z Ziemi w Obłoki; a pod nia ten napis Recto spectat vertice Calum". 
wanych zobowiązań. W zborze w Birżach niejaki Mikołaj Jakubonis za nieumyślne, ale śmiertelne postrzelenie matki, musiał przez trzy niedziele leżeć krzyżem podczas nabożeństwa, a w trakcie kazania musiał z muszkietem stać na stołku. W innych przypadkach, by potwierdzić dokonane przysięgą zobowiązania, trzeba było powtórzyć przysięge przy zborze kalwińskim $\mathrm{i}$ to niezależnie od konfesij ${ }^{78}$.

Druga połowa XVII wieku w historii kalwinizmu na Litwie zapisała się rosnącym naporem kontrreformacji, której owocem było zajmowanie przez księży oraz niszczenie w mniejszym lub większym stopniu zborów helweckich. Odszedł w przeszłość protektorat Radziwiłłów birżańskich, wygasł protektorat Bogusława Radziwiłła. Następne pokolenie tejże rodziny z neoficką gorliwością chciało zatrzeć w pamięci swoje kalwińskie dziedzictwo. Już kardynał i biskup wileński Jerzy Radziwiłł, syn Radziwiłła Czarnego, absolwent szkoły kalwińskiej w Wilnie i Nieświeżu urządził w 1581 roku pokazowe palenie heretyckich książek, za co spotkało go potępienie króla Stefana Batorego $^{79}$. Podczas potopu szwedzkiego zniszczono wiele zborów kalwińskich, sparaliżowana została administracja kościelna, zaniechano organizacji synodów. Śmierć i rozproszenie emigrujących z Litwy ministrów znacznie pogorszyły jakość służby kościelnej. Celem ataków jezuickich stały się teraz przede wszystkim duże ośrodki kalwinizmu na Litwie takie jak Słuck, Kiejdany czy Wilno. Ambicja jezuicką było przecież usunięcie stołecznego zboru poza mury miejskie, a potem jego całkowite zlikwidowanie ${ }^{80}$.

Do kolejnych strat przyczyniły się operujące na Litwie wojska rosyjskie, przekazując bezprawnie wiele budynków w ręce katolickie. Zniszczyły one np. zbór w Połocku (a tamtejsi jezuici zablokowali jego odbudowę̨), czy w Świętych Jeziorach, o który bój toczył dominikanin ks. Stetkiewicz. Padły zbory w Witebsku, Szacku, Hołowczynie, Połocku i Mińsku ${ }^{82}$. Zbór w Wiżunach

78 M. Kosman, Jednota litewska..., s. 31.

79 J. Tazbir, Historia kościoła katolickiego w Polsce 1460-1795, Warszawa 1966, s. 88.

80 J. Łukaszewicz, op.cit., s. 317. Zbór w Słucku, wymagający naprawy został zakwestionowany przez duchowieństwo katolickie, które uniemożliwiało jego remont pod kara 1000 kop groszy litewskich.

81 W. Krasiński, op.cit., s. 219.

82 J. Lukaszewicz, op.cit., s. 262. Autor wspomina tu o uprowadzaniu przez wojska w głąb Rosji kaznodziejów wraz z ich rodzinami. 
został „podarowany” ks. Kleczkowskiemu przez oficera rosyjskiego i to wystarczyło by ksiądz katolicki poczuł się jego pełnoprawnym właścicielem. Owe „darowizny” były przyczyną ciagnących się procesów sądowych, które musiał wszczynać Bogusław Radziwiłł od 1662 roku, próbując odzyskać budynki zborowe w Świadości, Wiżunach, Świętym Jeziorze, Serejach czy Słucku. Przy współpracy ze Stanisławem Niezabitowskim procesował się z hierarchią katolicką o zbory w Bielicy, Dubinkach, Nowogródku, Owancie i w samych Kiejdanach. Kapituła żądała od magnata stosownych dokumentów zaświadczających o kalwińskiej własności poszczególnych budynków. Te, przypomnijmy, miały szczęśliwie, w przeciwieństwie do ziem Korony, własną osobowość prawną i stosowne dokumenty fundacyjne. Bogusław udowadniał, że Krzysztof Radziwiłł nie przekazał w darze zboru w Wiżunach rodzinie Dorohostajskich, gdy ta dała go w użytkowanie katolikom (historyjkę tą wymyślił ks. Kleczkowski z Wiżun).

Ksiądz Szachowiecki z kolei świadczył, że w Żupranach nie było zboru kalwińskiego, a jedynie kościół katolicki próbował sądzić się z księciem Bogusławem o kolejne, rzekomo katolickie świątynie w Dubinkach i Bielicy. Duchowny ten był wyjątkowo uparty i odporny na przekupienie, ponieważ czasem wyciszenie wyimaginowanych pretensji dało załatwić się zazwyczaj przez darowiznę w postaci ziemi (czyli mówiąc dzisiejszym językiem przez zwykłą łapówkę). Roszczenia kierowane na ręce reprezentującego księcia Niezabitowskiego podpierał kopiami, jak zaświadczał, oryginalnych dokumentów darowizn. Ksiądz Kleczkowski siłą nawracał na katolicyzm chłopów w Wiżunach, doprowadzając do starcia, pobicia i uwięzienia rewizorów księcia oraz do stawiania w chałupach katolickich ołtarzyków. Już samo nazywanie zborów kościołami było dla księży dowodem na ich katolickie pochodzenie, podobnie jak dobudowanie do zboru w Wiżunach pomieszczenia, które potraktowano jako zakrystię, a więc dowód na katolickość budynku (w istocie miejsce do pochówku zmarłych) ${ }^{83}$.

83 J. Dyr, Akcja ratowania zborów kalwiniskich w Polsce, „Odrodzenie i Reformacja w Polsce”, nr XVII, 1972, s. 191-195, 201. Ów Kleczkowski potrafił nawet wyrzucać z grobów ciała ewangelików i połamać krzyż znajdujący się na jednej z nich, o co oskarżył komisarzy księcia. Dowodem na katolickość zborów miało być ich wystawne, w ocenie katolików, wyposażenie. 
Ciągnące się spory, szczególnie o zbór w Wiżunach, gdzie znajdowały się pochówki Radziwiłłowskie, seniorat i szkoła doprowadziły do zbrojnych zajazdów na zbory w Wiżunach i Serejach, po to, by odebrać je siła katolikom. Sprawa zboru wiżuńskiego nie została jednak rozwiązana aż do śmierci Bogusława Radziwiłła w 1669 roku. W rękach katolickich pozostały zbory Owancie, Świętym Jeziorze i Dubinkach. Wiżuny wróciły wprawdzie w helweckie ręce, ale niedługo potem przejęte zostały przez katolików, a kalwiniści musieli zbudować drugi zbór, który przetrwał do lat 30 . XVIII wieku. Po wiek XVIII toczono boje o Słuck, gdzie z silnym środowiskiem kalwinistów konfliktowali się sprowadzeni do miasta jezuici. Fizyczną ochronę dwóch sług, którzy „by przy zborze i mieszkaniu kaznodziejskim dla bezpieczeństwa od hultajstwa zostawali” Bogusław Radziwiłł musiał zapewnić zborowi w Nowogródku, który niestety został zburzony w listopadzie 1667 roku przez owo „hultajstwo”, podburzone zreszta przez jezuitów. Analizując działania magnata, uwikłanego w spory sądowe i w istocie bezbronnego wobec działań duchowieństwa i utrudnień ze strony aparatu administracyjnego, bez trudu dostrzeżemy jego bezradność. Nie ochronił on zajęcia przez księży zboru w Bielicy, mimo iż zaklinał się, mówiąc: „niech z tej choroby nie wstanę, jeśli tam kiedy w Bielicy był kościół katolicki”" ${ }^{\prime 4}$.

Budynki kalwińskie, szczególnie te leżące w niewielkich miejscowościach, w II połowie XVII wieku były bardzo często atakowane przez ludzi podburzanych przez jezuitów lub przez świeckich księży katolickich, stąd zawsze istniała potrzeba ich aktywnej i pasywnej obrony. Czasem spalenie zboru było wyrazem gorliwości nawróconego na katolicyzm ewangelika jak np. niejakiego Kamińskiego, który spalił zbory w Gawrach i w Giałowie w 1677 roku. Spaleniem tego kościoła zainteresowany był wcześniej sam biskup wileński Kiszka, który w 1614 roku sam nakazał podpalić zbór w Giałowie, ale w tym wypadku nie obeszło się bez kary i w 1620 roku duchownemu zasądzono odszkodowanie za dokonany czyn ${ }^{85}$. Ofiara podpalenia padł zbór w Gruźlach, pod który ogień podłożyli wspólnie Burbowie i Pruszyńscy, czy zbór w Pomuszach podpalony przez ks. Gudowicza. Zbór

${ }^{84}$ Ibidem, s. 205. Zbór w Bielicy ostał się jednak w rękach kalwińskich bowiem figuruje on jako helwecki w $1754 \mathrm{r}$.

${ }^{85}$ M. Kosman, Jednota litewska..., s. 36-37. 
w Kościuszynie zniszczył w 1655 roku inny apostata, podsędek trocki Aleksander Rajecki, a Hieronim Puzyna nie tylko zniszczył kościół w Linkowcu, ale również uzyskał wyrok skazujący dla tutejszych pastorów za rzekomo zabrane srebra kościelne. Ks. Ponikwicki w 1729 roku spalił zbór w Lubeczu, zabierając wcześniej z niego dzwon, a następnie zagarniając dworek, do którego przeniesiono nabożeństwa ${ }^{86}$.

Zniszczeń nie przetrwał zbór w Nowogródku, gdzie nie tylko spalono drewniany dom modlitwy, ale kalwinistów wyrzucono z murowanych piwnic, do których się przenieśli, przy okazji bezczeszcząc ciała innowierców złożone na miejscowym cmentarzu. Podobna rzecz wydarzyła się w Ojnarowiczach, gdzie w 1744 roku katolicy „kaplicę porąbali, trumny powywracali i ciała porozrzucali”. W 1678 roku franciszkanie spalili zbór w Węgrowie, a biskup łucki skutecznie pieczętował odbudowany budynek. Kościół w Birżach, który powstał w 1589 roku i nie przetrwał do pożaru miasta i zamku w 1704 roku, pochłaniając groby radziwiłłowskie, m.in. Krzysztofa Radziwiłła Pioruna ${ }^{87}$. Udawało się czasem ukarać sprawców zniszczeń, zasądzając zazwyczaj kary pieniężne. W przypadku zboru w Widuklach, spalonego przez członka rodziny Blinstrubów, trybunał miński zasądził w 1712 roku 2700 złotych kary oraz banicję doczesną i wieczną! Głową zapłacił Włoch Franco za wywołanie burd, w wyniku których w 1611 roku zniszczono zbór w Wilnie ${ }^{88}$.

Niebezpieczne dla stanu zachowania zborów na Litwie było uchwalenie przez sejm „niemy” w 1717 roku nakazu zburzenia wszystkich nowo zbudowanych kościołów. I choć tyczyć się to miało tylko nieodległej przeszłości, to brak dokładniejszego sprecyzowania ram czasowych tego nakazu mógł skutkować bezprawnym niszczeniem powstałych budynków. W 1722 roku gmina wileńska przegrała proces sądowy, który wytoczono jej jeszcze w 1640 roku. Przedmiotem sprawy było rzekome zagarnięcie przez kal-

${ }^{86}$ W. Krasiński, op.cit., s. 210-215.

87 Zbiór pomnikón reformacyi..., s. 128-129 oraz 161. W testamencie Piorun napisał, iż jego grób ma być oznaczony czerwoną choragwia, na której oprócz jego wizerunku miała być umieszczona inskrypcja biograficzna, wskazująca na cnoty zmarłego. Autor podaje, że wizerunek zboru zachował się w książce Eu. Tyszkiewcza, Biræ̌̀, St. Petersburg 1869.

88 W. Krasiński, op.cit., s. 217-226; J. Lukaszewicz, op.cit., s. 147. Tu opis napaści na zbór, pobicia ministrów i podpalenia budynku. 
winistów ziemi pocerkiewnej i postawienie na niej wieży kościelnej. Unici w 1671 roku znowu zaskarżyli ewangelików, w tym personalnie seniora zboru o to, że cegły ze starego zboru wykorzystali do naprawy ich kamienicy zw. konstantynowska. Ogłoszony wyrok kazał zwrócić działkę unitom jako bezprawnie zabraną im już w XVI wieku (mimo potwierdzenia własności dokonanej przez Stefana Batorego). Ponieważ grunt ewangelicki trafił już w tym czasie w ręce franciszkańskie przy parafii św. Michała, to zasądzono ewangelikom karę w wysokości 36000 złotych, a starszych zborowych skazano na banicję i infamię ${ }^{89}$. Sejm konwokacyjny w 1733 roku blokował możliwość organizacji synodów różnowierczych, czyniąc z ewangelików obywateli drugiej kategorii, zintensyfikowano ataki na budynki zborowe. Jednocześnie kalwiniści starali się regulować zaległe należności od Radziwiłłów birżańskich, którzy teraz należeli do obozu katolickiego. Dokumentem, na który się przy tym chętnie powoływano, był odnowiony przywilej Ludwiki Karoliny Radziwiłłówny z 20 czerwca 1687 roku ${ }^{90}$.

Pewna stabilizacja wyznaniowa zaistniała na terenie Litwy dopiero pod koniec XVIII i na początku XIX wieku, której efektem były prace remontowe prowadzone w takich zborach jak Kojdanów, Jamno, Niepokojczyce, Zabłudowo, Kiejdany, Szwabiszki, Sołomieście i Izabelinie. Jednota litewska nigdy jednak nie powróciła do stanu swej dawnej świetności.

\section{Summary}

\section{Calvinist architecture of the Grand Duchy}

Calvinist Reformation in Lithuania had a completely different look than in the Crown. It lacked strong urban centres in which Lutheranism would flourish. Calvinism was mainly supported by the nobility (Mikołaj "the Red" Radziwiłł and Mikołaj "the Black" Radziwiłł), who wanted to make this confession a state religion in case of the independence of the Grand Duchy of Lithuania. Radziwił’'s prob-

89 Wyroku szczęśliwie nie wykonano, zob. Zbiór pomnikón reformacyi..., s. 194-195.

90 LMAB, sygn. F 40/989, k. 2-13v., LMAB F 40 517, Zbór Stucki 1662-1823, s. 2, oraz LMAB, sygn. F 40/ 91, Akta z̧boru w Stucku, s. 23. Ludwika Karolina księżna Radziwiłłowa potwierdza przywileje i nadania ziemskie oraz finansowe w 1687 roku dla zborów w Słucku, Kopiskach, Kojdanowie, Lubeczańskiemu. Bielickiemu, Sieleckiemu i Dokudowskiemu, oryginalne przywileje zaginęły podczas wojen szwedzkich i moskiewskich. 
ably wanted to subordinate Sigismund Augustus to their influence and create a strong, own state. Calvinism was an independent religion to Catholicism and Orthodoxy. Building of Reformed churches was associated with colonization of Lithuania and the construction of its economy and political development. Too strong dependence of Calvinism on the first generation of the Radziwilł's families leaders, caused the successive generations of families attracted by Catholicism to fight against Calvinism and effectively undermined its dominant position. Finally, at the end of the seventeenth century, this religion has lost its sense of importance. Many churches were destroyed, many people changed religion.

The article is the first attempt of presenting the Reformed churches in Lithuania. It presents also a history of few churches (like main church in Vilno), furnishing of interiors (table for the Lord's Supper, on which there was a desk for the Brest bible, the pulpit - called the cathedral - and others. Text is a kind of supplement and a summary of research on the Calvinist architecture of the Grand Duchy. 
